\title{
Estradiol Improves Cerebellar Memory Formation by Activating Estrogen Receptor $\beta$
}

\author{
Corina E. Andreescu, ${ }^{1}$ Bogdan A. Milojkovic, ${ }^{1}$ Elize D. Haasdijk, ${ }^{1}$ Piet Kramer, ${ }^{2}$ Frank H. De Jong, ${ }^{2}$ Andrée Krust,${ }^{3}$ \\ Chris I. De Zeeuw, ${ }^{1,4}$ and Marcel T. G. De Jeu ${ }^{1}$ \\ Departments of ${ }^{1}$ Neuroscience and ${ }^{2}$ Internal Medicine, Erasmus Medical Center, 3000 DR Rotterdam, The Netherlands, ${ }^{3}$ Institut de Genetique et de \\ Biologie Moleculaire et Cellulaire, Centre National de la Recherche Scientifique/Inserm/University Louis Pasteur, College de France, 67070 Strasbourg, \\ France, and ${ }^{4}$ Netherlands Institute for Neuroscience, Royal Netherlands Academy of Sciences, 1000 GC Amsterdam, The Netherlands
}

Learning motor skills is critical for motor abilities such as driving a car or playing piano. The speed at which we learn those skills is subject to many factors. Yet, it is not known to what extent gonadal hormones can affect the achievement of accurate movements in time and space. Here we demonstrate via different lines of evidence that estradiol promotes plasticity in the cerebellar cortex underlying motor learning. First, we show that estradiol enhances induction of long-term potentiation at the parallel fiber to Purkinje cell synapse, whereas it does not affect long-term depression; second, we show that estradiol activation of estrogen receptor $\beta$ receptors in Purkinje cells significantly improves gain-decrease adaptation of the vestibulo-ocular reflex, whereas it does not affect general eye movement performance; and third, we show that estradiol increases the density of parallel fiber to Purkinje cell synapses, whereas it does not affect the density of climbing fiber synapses. We conclude that estradiol can improve motor skills by potentiating cerebellar plasticity and synapse formation. These processes may be advantageous during periods of high estradiol levels of the estrous cycle or pregnancy.

Key words: cerebellum; estrogen; motor learning; neuronal plasticity; estrogen receptor $\beta$; mutant mice

\section{Introduction}

Learning and memory are crucial for acquiring and storing new information, and these processes are potentially affected by hormones. The gonadal hormone estradiol (E2) has beneficial effects on the formation of hippocampus-dependent memory (Farr et al., 1995; O’Neal et al., 1996; Gibbs et al., 1998; Shors et al., 1998; Leuner et al., 2004; Rhodes and Frye, 2004). During the estrous cycle, pyramidal cells in the hippocampus are subject to major changes including morphological changes (Woolley and McEwen, 1993; Adams et al., 2001) and modifications in synaptic efficacy (Warren et al., 1995; Cordoba Montoya and Carrer, 1997; Good et al., 1999; Vouimba et al., 2000; Mukai et al., 2007). Yet, it is not known whether E2 also affects cerebellar memory formation, despite the prominent presence of estrogen receptors (ERs) in the cerebellum (Shughrue et al., 1997; Price and Handa, 2000). If activated ERs are involved in cerebellar memory formation, one expects that at least some forms of motor learning and cellular plasticity are affected concomitantly by E2. Moreover, if E2 action is mainly cortical and the relationship between the cellular and behavioral effects is causal in a direct manner, one

Received June 7, 2007; revised July 20, 2007; accepted Aug. 2, 2007.

This work was supported by the Netherlands for Health Research and Development VENI (M.T.G.D.J.), Netherlands for Health Research and Development, Neuro Bsik, Sensopac-EU, and Prinses Beatrix Fonds (C.I.D.Z.). We thank J. van der Burg, S. K. E. Koekkoek, M. Rutteman, and E. Dalm for technical assistance. We thank P. Chambon for supplying the $E R \beta$ mutant mice.

Correspondence should be addressed to Dr. Chris I. De Zeeuw, Department of Neuroscience, Erasmus Medical Center, Dr. Molewaterplein 50, 3000 DR Rotterdam, The Netherlands. E-mail: c.dezeeuw@erasmusmc.nl. DOI:10.1523/JNEUROSCI.2588-07.2007

Copyright $\odot 2007$ Society for Neuroscience $\quad$ 0270-6474/07/2710832-08\$15.00/0 expects that the behavioral effects on the learning are rather specific with relatively mild or no effects on motor performance (Welsh and Harvey, 1991; Jiménez-Díaz et al., 2004). Here we tested the impact of E2 on adaptation of the vestibuloocular reflex (VOR) after visuovestibular training (Robinson, 1976; Ito, 1991; De Zeeuw et al., 1998) (Fig. 1). The main type of plasticity that may underlie this form of cerebellar motor learning is historically thought to be long-term depression (LTD) at the parallel fiber to Purkinje cell synapse (Marr, 1969; Albus, 1971; Ito 1991). However, recent behavioral studies on VOR adaptation suggest that different plasticity mechanisms may be involved in increasing and decreasing VOR gains (Boyden et al., 2003; De Zeeuw and Yeo, 2005). Induction of LTD at the parallel fiber to Purkinje cell synapse may be responsible for increasing the gain (Hansel et al., 2006), whereas other mechanisms such as long-term potentiation (LTP) at the same synapse may contribute to decreasing the gain (Hansel et al., 2001; Lev-Ram et al., 2002; Boyden et al., 2003; Coesmans et al., 2004). Considering the impact of E2 on hippocampal memory formation (Leuner et al., 2004; Rhodes and Frye, 2004; Mukai et al., 2007), one might expect E2 to affect LTP rather than LTD in the cerebellum. Thus, the present experiments were designed to study the effects of E2 on LTP at the parallel fiber to Purkinje cell synapse, on gaindecrease training of the VOR, and on the morphology of synaptic inputs to the Purkinje cells. In addition, we investigated the distribution of E2 receptors in the mouse flocculus, which is known to be the main cerebellar lobule involved in the control of VOR adaptation (Ito, 1991; Lisberger et al., 1994; Blazquez et al., 2007). Together, these studies should shed 


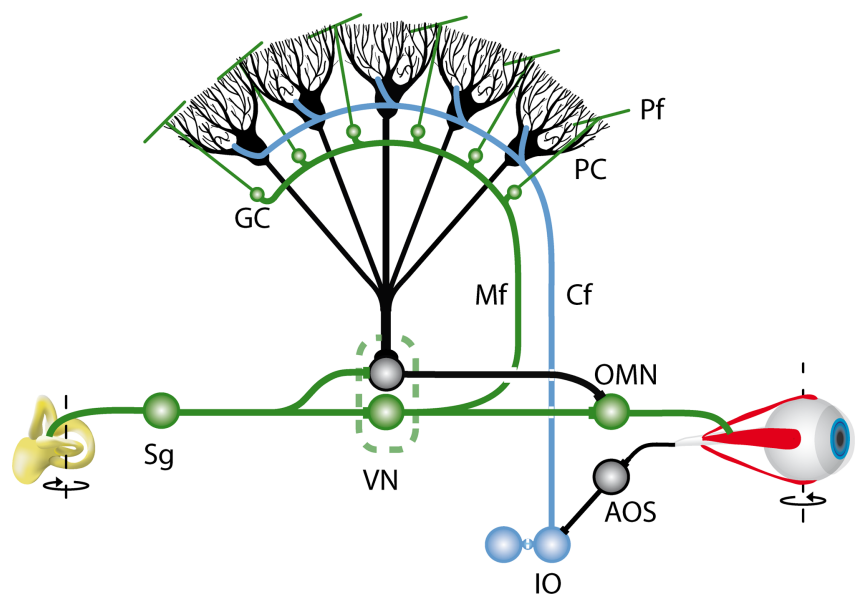

Figure 1. Scheme showing VOR circuitry. The VOR is an eye movement reflex that stabilizes retinal images during head movements (Collewijn and Grootendorst, 1979; Iwashita et al., 2001; Van Alphen and De Zeeuw, 2002; Boyden et al., 2004; Faulstich et al., 2004; Stahl, 2004). Primary afferents from the vestibular system [Scarpa's ganglion (Sg)] converge on second-order vestibular nuclei neurons $(\mathrm{VN})$ that innervate the oculomotor nucleus (OMN) to control eye movements. Information about head movements reaches the cerebellar cortex via the mossy fibers (Mf) innervating the granule cells (GC) that generate parallel fibers (Pf). Information about retinal slip, processed by the accessory optic system (AOS) and inferior olive (I0), reaches the cerebellar cortex via the climbing fibers (Cf). This information is processed in the Purkinje cells $(P C)$, which form the sole output of the cerebellar cortex. We tested the effect of E2 on motor performance and motor learning by investigating the VOR in the dark, before and after visuovestibular training. This reflex can be altered by the cerebellar side loop that can modulate the activity of the vestibular nuclei.

light on the potential facilitating role of E2 in motor memory formation.

\section{Materials and Methods}

Subjects. A total of 70 female C57BL/ 6 mice (The Jackson Laboratory, Bar Harbor, ME), 17 male C57BL/6 mice, and 8 Purkinje cell-specific ER $\beta$ knock-out female mice (L7-ER $\beta$ ) were housed on a $12 \mathrm{~h}$ light/dark cycle with food and water available ad libitum and subjected to the various tests described below. In one group of C57BL/6 females (Eovx mice), E2 levels were fixed at a high level by ovariectomy (OVX) and subsequent daily subcutaneous injections of $5 \mu \mathrm{g}$ of estradiol benzoate dissolved in $0.1 \mathrm{ml}$ sesame oil, whereas in another group of C57BL/6 females (Covx mice), E2 levels were kept at a constant low level by OVX and subsequent daily subcutaneous injections of only $0.1 \mathrm{ml}$ of sesame oil. In addition, we investigated groups of intact females and males for control. The Purkinje cell-specific ER $\beta$ mutants were generated by crossing flox-ER $\beta$ mutant mice (Dupont et al., 2000) with L7-cre mice (Barski et al., 2000). All experiments described below were performed blindly, and all animal procedures described below were in accordance with the rules of the ethical committee of the Erasmus Medical Center, Rotterdam.

Hormonal status. To check the hormonal status in female mice, daily vaginal smears were taken. To confirm this hormonal status, blood and uterus were collected on the day of the last experiment. In intact mice also, ovaries were collected. Levels of E2 were estimated using an ultrasensitive double-antibody radioimmunoassay (Diagnostic Systems Laboratories, Webster, TX). Eovx mice had uterus weights and serum E2 levels that were significantly higher than in Covx mice (both $p<0.001, t$ tests) (Table 1). Intact females in proestrus day had a bigger uterus, less follicles of class IV (diameter, 310-370 $\mu \mathrm{m}$ ), more follicles of class V (diameter, $>370 \mu \mathrm{m}$ ), and a higher E2 level than females in diestrus day (all $p<0.001$, two-tailed paired $t$ tests) (Table 1 ).

Electrophysiology. Sagittal slices of the cerebellar vermis $(200 \mu \mathrm{m})$ were prepared from 6- to 8-week-old C57BL/6 females (OVX females that received daily subcutaneous injection for $14 \mathrm{~d}$; Eovx, $n=10$; Covx, $n=$ $10)$ and males $(n=10)$. Slices were kept in artificial CSF containing (in mм) $124 \mathrm{NaCl}, 5 \mathrm{KCl}, 1.25 \mathrm{Na}_{2} \mathrm{HPO}_{4}, 2 \mathrm{MgSO}_{4}, 2 \mathrm{CaCl}_{2}, 26 \mathrm{NaHCO}_{3}$, and 10 D-glucose bubbled with $95 \% \mathrm{O}_{2}$ and $5 \% \mathrm{CO}_{2}$ and supplemented with $20 \mu \mathrm{g}$ of bicuculline methiodine to block $\mathrm{GABA}_{\mathrm{A}}$ receptors (Coesmans et al., 2004). Whole-cell patch-clamp recordings were performed at room temperature. The recording electrodes were filled with a solution containing (in mM) $9 \mathrm{KCl}, 10 \mathrm{KOH}, 120 \mathrm{~K}$ gluconate, $3.48 \mathrm{MgCl}_{2}, 10$ HEPES, $4 \mathrm{NaCl}, 4 \mathrm{Na}_{2} \mathrm{ATP}, 0.4 \mathrm{Na}_{3} \mathrm{GTP}$, and 17.5 sucrose, $\mathrm{pH}$ 7.3. The holding potential of Purkinje cells in voltage-clamp mode ranged between -65 and $-75 \mathrm{mV}$. Paired-pulse facilitation (PPF) was investigated by stimulating the parallel fibers with two $3 \mu \mathrm{A}$ pulses with an interval of $50 \mathrm{~ms}$ (pulse width, $700 \mu \mathrm{s}$; pair-pulse frequency, $0.05 \mathrm{~Hz}$ ) and by recording the responses in voltage-clamp mode. For tetanization, cells were switched to the current-clamp mode and parallel fibers were stimulated either alone (LTP) or in combination with climbing fibers (LTD). By measuring the PPF ratio, the presynaptic or postsynaptic nature of LTP and LTD can be estimated. The facilitated response to the second pulse is attributable to a very short-term enhancement in synaptic efficacy that is caused by residual presynaptic $\mathrm{Ca}^{2+}$, facilitating more transmitter release. A presynaptic form of long-term plasticity is coupled to alteration in the PPF ratio because it affects the transmitter release mechanism, whereas the postsynaptic form of long-term plasticity does not change the PPF ratio because the transmitter release mechanism is not affected by this plasticity change (Zucker, 1989; Lev-Ram et al., 2002; Coesmans et al., 2004). Recordings were excluded from the study if the access or series resistance varied $>15 \%$ during the experiment.

Behavioral tests. Three days before the behavioral tests, the mice received a prefabricated piece equipped with two nuts cemented to the skull so as to be able to fixate their head in a restraining device (Andreescu et al., 2005). The surgical procedures were performed under general anesthesia using a mixture of isofluoran (Isofloran, 1-1.5\%; Rhodia Organique Fine, Paris, France) and oxygen. In OVX mice, angular optokinetic reflex (OKR), VOR, and visually enhanced VOR (VVOR) were measured $\left( \pm 5^{\circ}, 0.2-1 \mathrm{~Hz}\right)$. Before VOR recordings, $4 \%$ pilocarpine (Laboratories Chauvin, Montpellier, France) was used to limit the pupil dilatation in darkness for video detection. VOR gain-decreases (VOR learning) were induced by presenting in phase sinusoidal vestibular and visual stimuli $\left( \pm 5^{\circ}, 0.6 \mathrm{~Hz}\right)$ for $50 \mathrm{~min}$. Before and after training, VOR was measured $\left( \pm 5^{\circ}, 0.6 \mathrm{~Hz}\right)$. OKR gain-increases (OKR learning) were induced by presenting $180^{\circ}$ out-of-phase sinusoidal vestibular and visual stimuli $\left( \pm 5^{\circ}, 0.6 \mathrm{~Hz}\right)$ for $50 \mathrm{~min}$. OKR was measured before and after training $\left( \pm 5^{\circ}, 0.6 \mathrm{~Hz}\right)$. The following experimental protocol was used for Eovx and Covx mice: day 0-OVX; day 17-18-OKR, VOR, and VVOR; day 19-VOR adaptation; day 20-VOR; day 26-OKR adaptation; and day 27-OKR measurements. Mice were treated daily with E2 or solvent between days 0 and 28. Between the measurements done on days 19-20 and 26-27, mice were kept in complete darkness. Intact C57BL/6 female mice were presented with VOR gain-decrease paradigm for $30 \mathrm{~min}$ on one specific day of the estrous cycle (i.e., diestrus or proestrus), and VOR was measured not only at the beginning and the end of the training but also every $10 \mathrm{~min}$. Intact L7-ER $\beta$ female mice were presented with the VOR gain-decrease paradigm in proestrus day. Intact male mice were presented with the VOR gain-decrease paradigm for $1 \mathrm{~d}$. Video eye movement recording and data analysis were performed as described previously (Stahl et al., 2000; Andreescu et al., 2005).

Morphology. Cerebellar slices $(40 \mu \mathrm{m})$ from 16-week-old females were processed for light microscopy (Price and Handa, 2000). In short, slices were rinsed four times for $10 \mathrm{~min}$ in Tris-buffered saline (TBS; pH 7.6, $0.05 \mathrm{M}$ ), followed by a preincubation of $1 \mathrm{~h}$ in ice-cold TBS containing $10 \%$ normal horse serum and $0.5 \%$ Triton. Subsequently, sections were incubated with a primary antibody for $48 \mathrm{~h}$ at $4^{\circ} \mathrm{C}[\mathrm{ER} \alpha(1: 200)$ and ER $\beta$-N-term (1:1000); Affinity BioReagents, Golden, CO], rinsed four times for $10 \mathrm{~min}$ in TBS, incubated with a secondary antibody (1:200) for $90 \mathrm{~min}$ at room temperature, and rinsed again four times for $10 \mathrm{~min}$ in TBS. Finally, tissue was incubated for $90 \mathrm{~min}$ at room temperature in ABC Elite (PK 6100; Vector Laboratories, Burlingame, CA), rinsed three times for $10 \mathrm{~min}$ in TBS, and rinsed three times for $10 \mathrm{~min}$ in $0.05 \mathrm{M}$ Tris $\mathrm{HCl}$, followed by a DAB staining.

The flocculus (from OVX females that received a daily subcutaneous injection for $14 \mathrm{~d}$; Eovx, $n=8$; Covx, $n=8$ ) was processed for electronic microscopy (CM 100; Philips, Eindhoven, The Netherlands) and labeled 
with an antibody against calbindin (De Zeeuw et al., 1989; Koekkoek et al., 2005). The "conventional" estimation procedure was used to determine the synaptic density at the parallel fiber and climbing fiber to Purkinje cell, respectively (Woolley and McEwen, 1992). From each brain (80 electron micrographs), the amount of synapses $\left(\mathrm{N}_{\mathrm{s}}\right)$ was counted, and the total postsynaptic density area $\left(\mathrm{PSD}_{\mathrm{A}}\right)$ and the PSD perimeter $\left(\mathrm{PSD}_{\mathrm{P}}\right)$ were measured (Soft Imaging System Analysis 3.0; Olympus Imaging America, Center Valley, PA). In addition, the exact area sampled (corrected A) was computed by subtracting all areas covered by large synapse-free structures from the total area sampled. Estimated synapse density $\left(D_{s}\right)$ was calculated according to the following: $\mathrm{D}_{\mathrm{s}}=\left(\mathrm{N}_{\mathrm{s}} /\right.$ corrected $\left.\mathrm{A}\right) \times \mathrm{PSD}_{\mathrm{A}}$.

Statistical tests. Data are presented as mean \pm SEM. For statistical comparisons, we used the two-way ANOVA with repeated measures followed by a post hoc analysis, if required, and the two-sample Student's $t$ tests (SPSS 11.0; SPSS, Chicago, IL).

\section{Results \\ E2 improves LTP but not LTD in \\ Purkinje cells}

To find out whether E2 exerts a potentiating effect on plasticity at the parallel fiber to Purkinje cell synapse, we investigated the level of induction of LTP in both Eovx and Covx female mice as well as in males (Fig. 2A). LTP was induced by stimulating the parallel fiber input at $1 \mathrm{~Hz}$ for $5 \mathrm{~min}$ in current-clamp mode (Lev-Ram et al., 2002; Coesmans et al., 2004). After tetanization, EPSC amplitude was significantly increased to $145.8 \pm 2.7 \%$ in Eovx mice $(n=10 ; t=37-42 \mathrm{~min}$ after; $p<0.001$, two-tailed paired $t$ test), to $117.7 \pm 1.5 \%$ in Covx mice ( $n=10 ; t=37-42$ min after; $p<0.001$, two-tailed paired $t$ test $)$, and to $121.6 \pm 0.1 \%$ in males $(n=9 ; t=37-42$ min after; $p<0.001$, two-tailed paired $t$ test). The differences in LTP induction among Eovx mice and Covx mice as well as among Eovx mice and males were significant $(p<0.01$ and $p<0.02$, respectively; two-way ANOVA) and probably of a postsynaptic nature, because the PPF ratio did not change after tetanization (Eovx mice: $98.8 \pm 0.5, p=0.57$; Covx mice: $97.8 \pm 0.4, p=0.99$; males: $98.6 \pm 0.3, p=0.70$; two-tailed paired $t$ test) (Fig. $2 B, D$ ). Moreover, because the input resistance, rise time kinetics, decay time, and amplitude of the EPSCs were not significantly different among Eovx mice and Covx mice $(p=0.55, p=0.75, p=0.72$, and $p=0.76$ respectively; two-tailed paired $t$ test) (Table 2 ), it appears unlikely that the differences in LTP induction are biased because of potential differential effects of E2 on basal synaptic transmission at the parallel fiber to Purkinje cell synapse in the three groups of animals.

To investigate whether the impact of E2 on plasticity at the parallel fiber to Purkinje cell synapse is specific for induction of LTP, we also investigated its effect on induction of LTD. We therefore subjected slices of both Eovx and Covx female mice as well as of normal males to paired stimulations of parallel fibers

A are mean \pm SEM.

Table 1. Vaginal smear feature, uterus size, number of follicles, and E2 level in C57BL/6 female mice

\begin{tabular}{|c|c|c|c|c|c|}
\hline \multirow[b]{2}{*}{ Mice } & \multirow[b]{2}{*}{ Vaginal smear } & \multirow{2}{*}{$\begin{array}{l}\text { Uterus } \\
\text { (mg) }\end{array}$} & \multicolumn{2}{|l|}{ Follicles } & \multirow{2}{*}{$\begin{array}{l}\mathrm{E} 2 \\
(\mathrm{pmol} / \mathrm{L})\end{array}$} \\
\hline & & & Class IV & Class V & \\
\hline $\operatorname{Eovx}(n=9)$ & Irregularly shaped cornified cells & $132 \pm 7$ & & & $465 \pm 97$ \\
\hline $\operatorname{Covx}(n=9)$ & Leucocyte; few parabasal cells & $18 \pm 2$ & & & $<3$ \\
\hline Proestrus $(n=7)$ & Irregularly shaped cornified cells & $109 \pm 5$ & $1 \pm 1$ & $9 \pm 1$ & $58 \pm 2$ \\
\hline Diestrus $(n=8)$ & Leucocyte; few parabasal cells & $76 \pm 5$ & $7 \pm 1$ & $2 \pm 1$ & $49 \pm 1$ \\
\hline
\end{tabular}

2. E2 enhances LTP but not LTD $A, B$ Induction of parallel fiber-LTP by parallel fiber (PF) stimulation at $1 \mathrm{~Hz}$ for $5 \mathrm{~min}$ me. C, D, Induction of parallel fiber-LTD by parallel fiber (PF) and climbing fiber (CF) stimulation at $1 \mathrm{~Hz}$ for $5 \mathrm{~min}$ nerated the same response in slices from Eovx (square), Covx (triangle), and male (diamond) mice. Traces show superimposed

Table 2. Basal synaptic parameters from Purkinje cells from Covx, Eovx, and male mice

\begin{tabular}{lcllll}
\hline Mice & Rinput $(\mathrm{M} \Omega)$ & $\begin{array}{l}\text { EPSC amplitude } \\
(\mathrm{pA})\end{array}$ & $10-90 \%$ rise time $(\mathrm{ms})$ & Decay time constant $(\mathrm{ms})$ & $\begin{array}{l}\text { PPF ratio } \\
(\%)\end{array}$ \\
\hline $\operatorname{Covx}(n=5)$ & $94.7 \pm 8.2$ & $-349.0 \pm 23.0$ & $3.1 \pm 0.2$ & $19.7 \pm 3.1$ & $97.8 \pm 0.4$ \\
Eovx $(n=5)$ & $105.4 \pm 14.8$ & $-374.4 \pm 5.8$ & $3.0 \pm 0.2$ & $21.0 \pm 1.4$ & $98.8 \pm 0.5$ \\
Male $(n=5)$ & $92.6 \pm 4.9$ & $-350.2 \pm 6.0$ & $3.0 \pm 0.1$ & $21.6 \pm 1.1$ & $98.6 \pm 0.3$ \\
\hline
\end{tabular}

All values are mean \pm SEM. R input, Input resistance.

and climbing fibers at $1 \mathrm{~Hz}$ for $5 \mathrm{~min}$ in current-clamp mode (Fig. $2 C)$. After tetanization, the amplitude of the EPSC was significantly decreased to $85.8 \pm 0.6 \%$ in Eovx mice $(t=37-42 \mathrm{~min}$ after; $p<0.001$, two-tailed paired $t$ test; $n=7)$ and to $82.2 \pm$ $0.7 \%$ in Covx mice $(t=37-42$ min after; $p<0.001$, two-tailed paired $t$ test; $n=6)$. These values were not significantly different ( $p=0.49$, two-way ANOVA). Interestingly, the level of LTD induction in Purkinje cells of male mice was also similar to those of Covx and Eovx female mice ( $p=0.18$ and $p=0.40$, respectively, two-way ANOVA, post hoc LSD). We conclude that E2 significantly increases induction of LTP, but not of LTD, at the parallel fiber to Purkinje cell synapse via a postsynaptic mechanism.

E2 improves VOR motor learning but not motor performance When basic eye movement performance was measured in female mice that were ovariectomized and received daily subcutaneous 

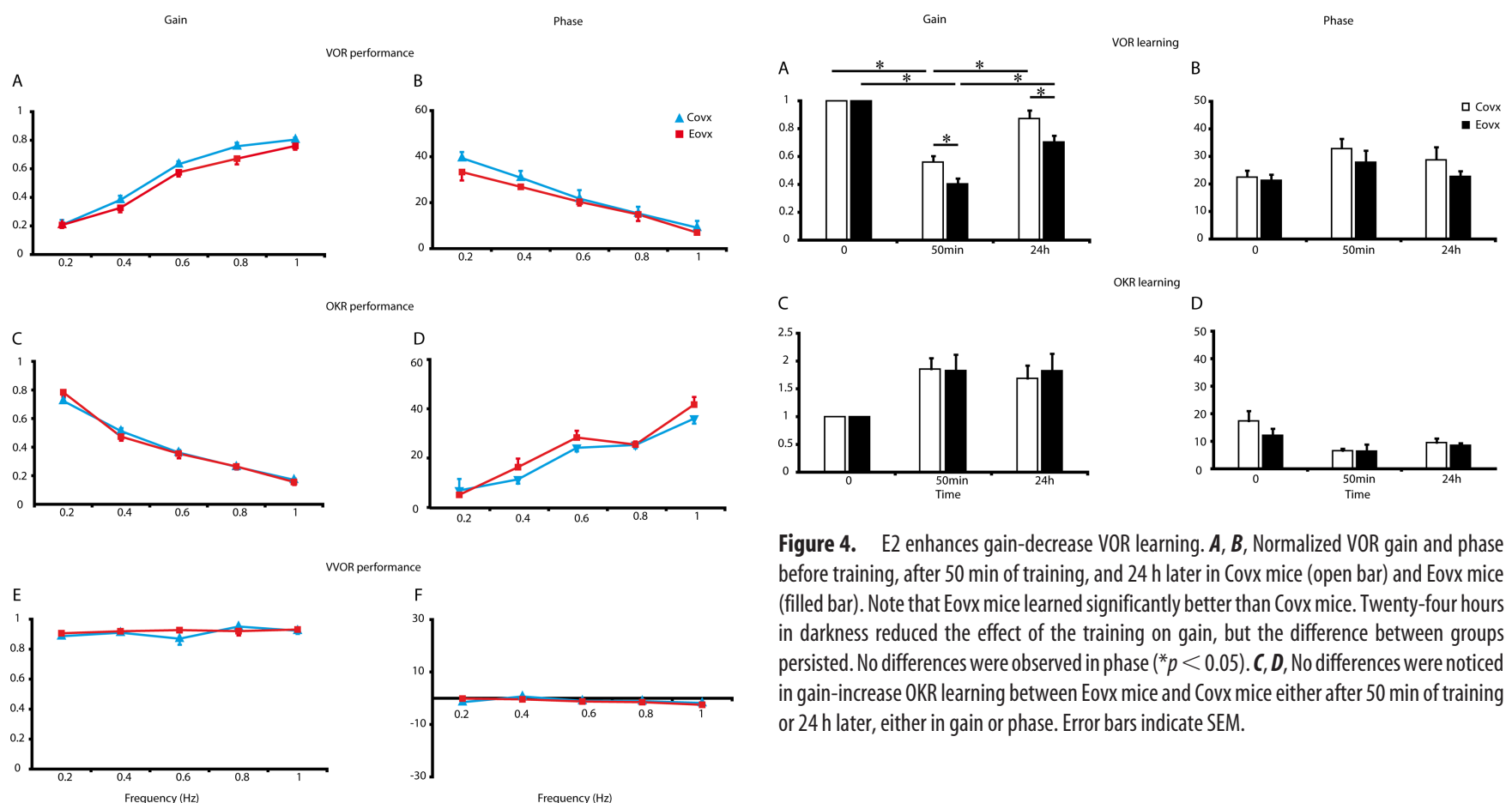

OKR learning

Figure 4. E2 enhances gain-decrease VOR learning. $A, B$, Normalized VOR gain and phase before training, after $50 \mathrm{~min}$ of training, and $24 \mathrm{~h}$ later in Covx mice (open bar) and Eovx mice (filled bar). Note that Eovx mice learned significantly better than Covx mice. Twenty-four hours in darkness reduced the effect of the training on gain, but the difference between groups persisted. No differences were observed in phase $\left({ }^{*} p<0.05\right)$. C, $\boldsymbol{D}$, No differences were noticed in gain-increase OKR learning between Eovx mice and Covx mice either after 50 min of training or $24 \mathrm{~h}$ later, either in gain or phase. Error bars indicate SEM.

Figure 3. E2 does not affect motor performance. Robust compensatory eye movements are generated by head rotations in the dark (VOR) $(\boldsymbol{A}, \boldsymbol{B})$, by environment rotations in the light (OKR) $(\boldsymbol{C}, \boldsymbol{D})$, and by head rotations in light (VVOR) $(\boldsymbol{E}, \boldsymbol{F})$ with frequencies ranging from 0.2 to 1 $\mathrm{Hz}$ at an amplitude of $5^{\circ}$. The amplitude (gain) was computed as the ratio of eye velocity to stimulus velocity; timing (phase) was expressed as the difference (in degrees) between the eye velocity and stimulus velocity. In all conditions, no differences were observed in gain or phase between mice with low (Covx; triangle) and high (Eovx; square) levels of E2 (all $p>0.05$, 2-way ANOVA). Error bars indicate SEM.

injections with either estradiol benzoate dissolved in sesame oil (Eovx) or sesame oil alone (Covx), VOR amplitude (i.e., gain) and timing (i.e., phase) of the VOR in mice with a high level of E2 (Eovx, $n=9$ ) were similar to those in mice with a low level of E2 (Covx, $n=9 ; p=0.14$ and $p=0.31$, respectively, two-way ANOVA) (Fig. $3 A, B$ ). In addition, eye movement responses of Eovx mice to visual stimulation (OKR) (Fig. 3C,D) and to head rotation in light (VVOR) (Fig. $3 E, F$ ) were also similar to those of Covx mice (OKR gain, $p=0.98$; OKR phase, $p=0.12$; VVOR gain, $p=0.91$; VVOR phase, $p=0.30$; two-way ANOVA) and showed the classical relationship to stimulus frequency (Fig. 3). Consequently, we conclude that E2 does not influence the general eye-motor performance.

In contrast, when both groups of mice were subjected to a visuovestibular training paradigm in which head rotation was paired for $50 \mathrm{~min}$ with in-phase rotation of the visual environment $\left( \pm 5^{\circ}, 0.6 \mathrm{~Hz}\right)$, significant differences were observed (Fig. $4 A, B)$. The training paradigm induced a robust decrease in VOR gain of $60 \%$ in Eovx mice (from an initial value of $0.56 \pm 0.03$ to a final value of $0.23 \pm 0.02 ; n=9)$, whereas in the Covx mice, a significantly smaller learning effect was observed $(p<0.001$, two-tailed paired $t$ test; $44 \%$ from $0.57 \pm 0.03$ to $0.32 \pm 0.03$; $n=7)$. In both groups, the change in VOR gain induced by the training was reduced after spending $24 \mathrm{~h}$ in darkness (Fig. $4 \mathrm{~A}$ ) (Eovx, $p<0.001$; Covx, $p<0.001$; two-tailed paired $t$ test), but the difference between Eovx and Covx mice was preserved (Fig. $4 A)(p<0.02$, two-tailed paired $t$ test $)$. In contrast, no significant differences were observed in phase values (Fig. $4 B$ ) (after training, $p=0.40$; at $24 \mathrm{~h}, p=0.22$; two-tailed paired $t$ test). This

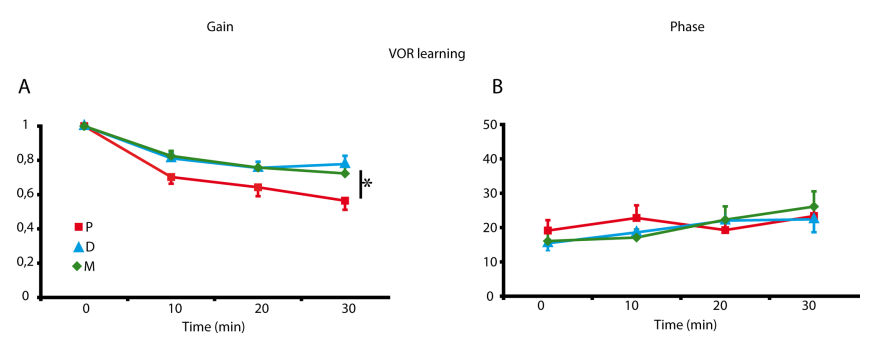

Figure 5. Motor learning is enhanced by endogenous high levels of the E2. A, B, Thirty minutes of training induced a higher VOR gain-decrease in female mice with natural high levels of E2 [proestrus (P); squares] than in female mice with natural low levels of E2 [diestrus (D); triangles] or than in male mice (M; diamonds). No differences were observed in phase. ${ }^{*} p<$ 0.05 . All values are mean $\pm \mathrm{SEM}$.

discrepancy may be explained by the fact that the timing of the response (VOR phase) might be regulated by different forms of plasticity or at different places that are not subject to estrogen action (Lisberger et al., 1983; Faulstich et al., 2004; De Zeeuw and Yeo, 2005).

As a control, OKR adaptation was tested by pairing head rotation with out of phase rotation of the environment. All mice responded to the training stimulus by adaptively increasing OKR gain and decreasing OKR phase, but no significant differences were observed in gain or phase between OVX mice with and without E2 replacement (after training for gain, $p=0.94$; after training for phase, $p=0.95$; at $24 \mathrm{~h}$ for gain $p=0.70$; at $24 \mathrm{~h}$ for phase, $p=0.60$; two-tailed paired $t$ tests) (Fig. $4 C, D$ ).

Thus, artificially generated high levels of E2 specifically improved gain-decrease motor learning and memory maintenance, whereas the overall motor performance was unaffected. The basic motor performance remained normal because the visuovestibular system was not challenged in this test situation.

\section{Endogenously induced high levels of E2 are sufficient to alter motor learning}

Artificially induced changes in levels of motor learning do not necessarily imply functional differences that are relevant under 
physiological circumstances. To test to what extent variations in the endogenous levels of E2 affect motor learning, VOR adaptation was measured in "intact" (nonOVX) female mice at different days of their normal estrous cycle. In female mice in diestrus (low E2 level of $49 \pm 1 \mathrm{pmol} / \mathrm{L}$; $n=8), 30 \mathrm{~min}$ of training resulted in a change in VOR gain of $22 \%$, whereas in mice in proestrus (high E2 level of $58 \pm 2$ $\mathrm{pmol} / \mathrm{L} ; p<0.001$, two-tailed paired $t$ test; $n=7)$, the same training resulted in a significantly greater change of $44 \%(p<$ 0.005, two-way ANOVA) (Fig. $5 A$ ). The same paradigm applied to male mice (E2 level of $48 \pm 14 \mathrm{pmol} / \mathrm{L} ; n=7$ ) induced a change in the VOR gain of $28 \%$, which was comparable to the change observed in female mice in diestrus ( $p=0.47$, two-way ANOVA, post hoc LSD) (Fig. 5A) but significantly smaller than that in females in proestrus $(p<0.03$, two-way ANOVA, post hoc LSD). No significant changes were found for phase values (all $p>0.5$, twoway ANOVA, post hoc LSD) (Fig. 5B). Thus, female mice with endogenous high levels of E2 show significantly better levels of motor learning than females with endogenous low levels of E2 or male mice.
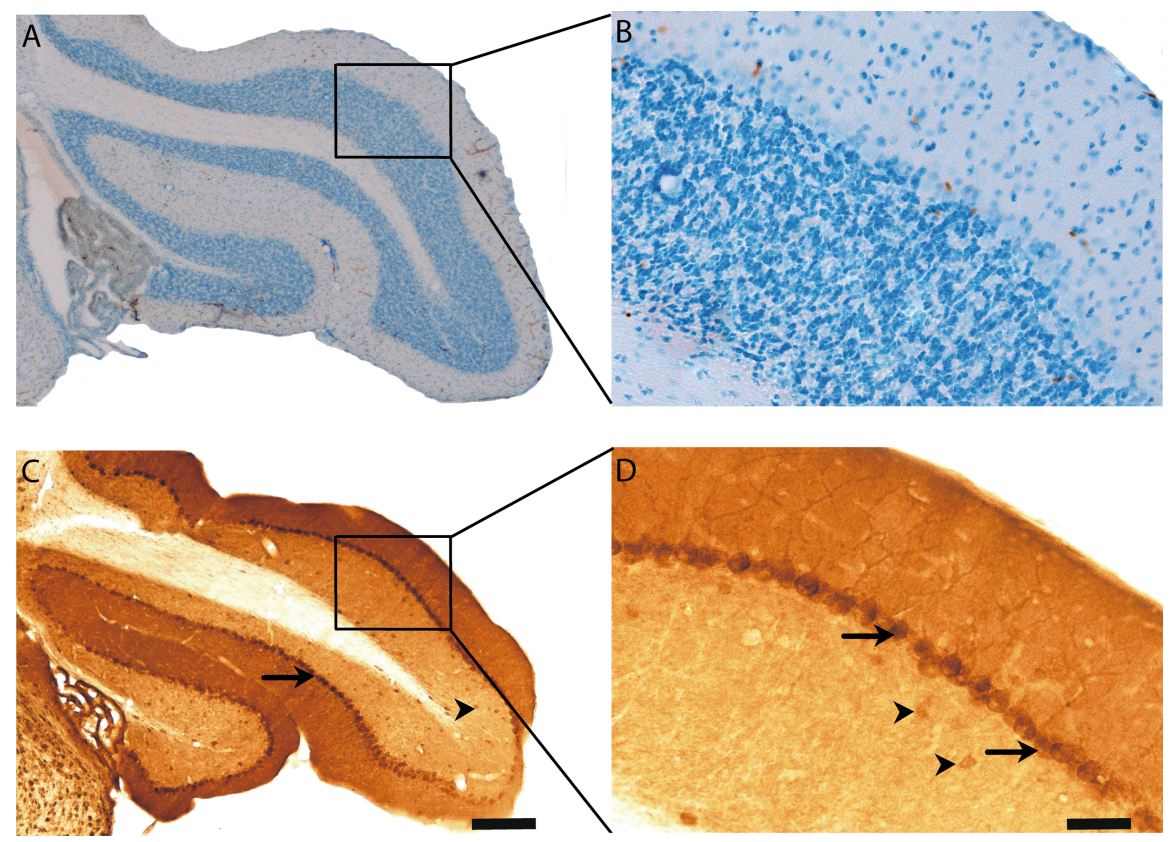

Figure 6. E2 receptor expression in the vestibulocerebellum. $A, B, E R \alpha$ immunoreactivity in sagittal cerebellar slices counterstained with thionin reveals no $E R \alpha$ in any of the cerebellar neurons. $C, D, E R \beta$ immunoreactivity in sagittal cerebellar slices shows a high expression of the ER $\beta$. ER $\beta$ is present in Purkinje cells (arrows) and Golgi cells (arrowheads) in the flocculus and paraflocculus. Scale bars: $A, C, 400 \mu \mathrm{m} ; \boldsymbol{B}, \boldsymbol{D}, 100 \mu \mathrm{m}$.

$\mathrm{ER} \beta$ but not $\mathrm{ER} \boldsymbol{\alpha}$ are present in the adult vestibulocerebellum In the developing cerebellum, both $\operatorname{ER} \alpha$ and $\operatorname{ER} \beta$ are localized in Purkinje cells, granular cells, and molecular layer interneurons (Jakab et al., 2001; Perez et al., 2003). ER $\beta$ has also been shown to occur in the adult cerebellum (Price and Handa, 2000), but it is still not clear to what extent it is located in the vestibulocerebellum (i.e., the area that controls adaptation of the VOR) (Robinson, 1976). We therefore investigated the localization of both $\alpha$ ERs $(\operatorname{ER} \alpha)$ and $\beta$ ERs $(\operatorname{ER} \beta)$ in the flocculus and paraflocculus of the vestibulocerebellum in the adult mouse. Although $\mathrm{ER} \alpha$ expression could not be detected in the flocculus or paraflocculus (Fig. 6A,B), ER $\beta$ occurred in the cell soma and dendrites of Purkinje cells in both flocculus and paraflocculus as well as in their terminals in the vestibular nuclei (Fig. $6 C, D$ ). In addition, labeling for ER $\beta$ could be observed in Golgi cells in the granular layer of the flocculus and paraflocculus (Fig. 6C,D). Therefore, E2 may exert its effects on VOR adaptation either by directly activating the Purkinje cells in the flocculus and/or via activation of the Golgi cells.

\section{Activation of ER $\beta$ in Purkinje cells contributes to enhanced adaptation}

To further pinpoint the location of the ERs responsible for the differences in motor learning, we created and tested mouse mutants in which ER $\beta$ was specifically removed in Purkinje cells (L7-ER $\beta-/-)$. When female L7-ER $\beta-/-$ mice were presented in the proestrus day with the training paradigm, the training still induced a change in VOR gain of $29 \%$ in L7-ER $\beta-/-$ mice $(n=$ 4) (Fig. 7A). However, in the female L7-ER $\beta$ wild-type littermates, we observed a significantly larger effect on the adaptation (51\%; $n=4 ; p<0.05$, two-way ANOVA) (Fig. $7 A$ ), indicating that the activation of the ER $\beta$ in the Purkinje cells plays an important role in this form of motor learning. No significant

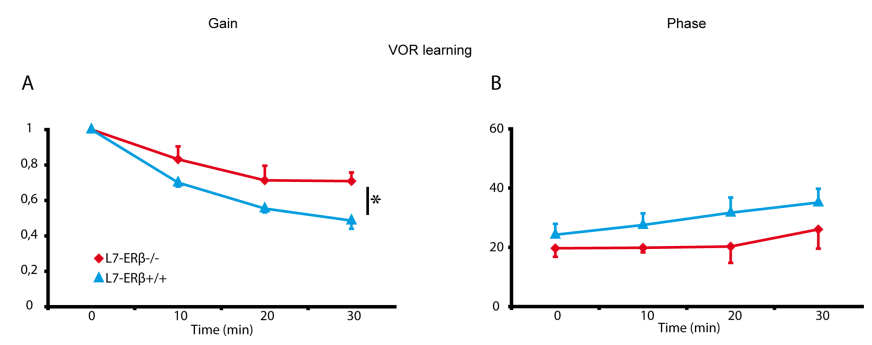

Figure 7. Motor learning is enhanced by the presence of the ER $\beta$ in the Purkinje cells. $\boldsymbol{A}, \boldsymbol{B}$, Thirty minutes of training induced a higher VOR gain-decrease in L7-ER $\beta+/+$ littermates (triangles) than in L7-ER $\beta-/-$ (diamonds). No significant differences were observed in phase. ${ }^{*} p<0.05$. All values are mean \pm SEM.

changes were found in the phase ( $p=0.17$, two-way ANOVA) (Fig. $7 B$ ). Thus, by subjecting mice in which the $\mathrm{ER} \beta$ receptor is specifically ablated in Purkinje cells (i.e., the L7-ER $\beta-/-$ mutants) to the visuovestibular training paradigms, we show here that activation of ER $\beta$ in Purkinje cells is sufficient to enhance gain-decrease adaptation of the VOR in the Eovx mice and in the intact mice in proestrus described above.

\section{E2 alters parallel fiber to Purkinje cell synapses at structural level}

The effects of E2 on synaptic efficacy described above may, in principle, be correlated to effects on the morphology of the synapses involved. We therefore investigated Purkinje cells of Eovx mice and Covx mice at the ultrastructural level. Cerebellar sagittal sections were stained against calbindin, processed for electron microscopy, and quantitatively analyzed at the level of the parallel fiber input (Fig. 8A,B). We found that high levels of E2 significantly increased the number of synapses (Eovx mice, $0.55 \pm 0.03$ / $\mu \mathrm{m}^{2}$; Covx mice, $0.47 \pm 0.02 / \mu \mathrm{m}^{2} ; p=0.051$, two-tailed paired $t$ test). The postsynaptic density area $\left(\mathrm{PSD}_{\mathrm{A}}\right)$ and the postsynaptic 

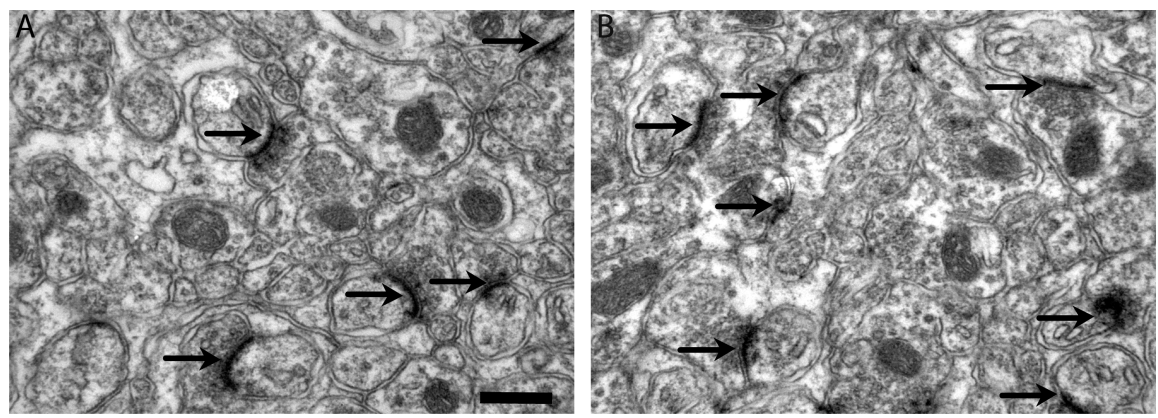

Figure 8. E2 increases synaptic density in the vestibulocerebellum. Electron micrographs of the molecular layer of the flocullus that are labeled with antibody against calbindin showing ultrastructural characteristics of Purkinje cell synapses in OVX mice that received oil $(\boldsymbol{A})$ or E2 $(\boldsymbol{B})$. Arrows mark synapses between Purkinje cell and parallel fibers. Scale bar, $0.5 \mu \mathrm{m}$.

density perimeter $\left(\mathrm{PSD}_{\mathrm{P}}\right)$ were slightly, but not significantly, increased in Eovx mice $(n=8)$ compared with those in Covx mice $(n=8)$. The $\mathrm{PSD}_{\mathrm{A}}$ area and $\mathrm{PSD}_{\mathrm{P}}$ in Eovx mice were $7788 \pm 515$ $\mathrm{nm}^{2}$ and $662 \pm 14 \mathrm{~nm}$, respectively, whereas those in Covx mice were $7177 \pm 287 \mathrm{~nm}^{2}$ and $634 \pm 15 \mathrm{~nm}$, respectively $(p=0.32$ and $p=0.18$, respectively, two-tailed paired $t$ test). However, when the synaptic density was considered (for formula, see Materials and Methods), it became apparent that the total postsynaptic area was significantly increased by $30 \%$ in Eovx mice (Eovx mice, $376 \pm 35$; Covx mice, $289 \pm 20 ; p<0.05$, two-tailed paired $t$ test). In contrast, the total postsynaptic surface area available per vibratome section at the climbing fiber to Purkinje cell synapse did not show any significant change ( $p=0.61$, two-tailed paired $t$ test). We conclude that E2 specifically enhances the availability of the synaptic complexes at the parallel fiber to Purkinje cell input.

\section{Discussion}

Our data show via different lines of evidence that the gonadal hormone E2 promotes cerebellar plasticity in a specific manner. We show that E2 enhances induction of LTP at the parallel fiber to Purkinje cell synapse, whereas it does not affect LTD; that E2 activation of ER $\beta$ receptors of Purkinje cells significantly improves gain-decrease adaptation of the VOR, whereas it does not affect gain-increase adaptation of the OKR or general eye movement performance; and that E2 increases the total size of the postsynaptic complex of the parallel fiber to Purkinje cell synapse, whereas it does not affect that of the climbing fiber synapse.

These data support one another, and they are in line with several other investigations. First, Boyden and colleagues (Boyden and Raymond, 2003; see also Miles and Eighmy, 1980; Van Alphen and De Zeeuw, 2002; Faulstich et al., 2004) pointed out that gain-decrease paradigms show different dynamics compared with those of gain-increase paradigms and that it is therefore unlikely that they both depend on LTD. Second, LTP induction is supposed to increase the insertion of AMPA receptors and thereby enlarge their postsynaptic complex, whereas LTD induction at these synapses could only decrease their size because of the endocytosis of these receptors and their associated protein complexes (Strata and Rossi, 1998; Hansel et al., 2001; Song and Huganir, 2002; Coesmans et al., 2004). Moreover, because climbing fiber activity can only promote LTD at the parallel fiber synapse (Coesmans et al., 2004), one does not expect a change at the climbing fiber synapse if the promoting effect of $\mathrm{E} 2$ is specific for LTP induction. Thus, although LTD and LTP do certainly not provide the only push-pull mechanisms in the olivocerebellar system (De Zeeuw et al., 2004), the present study does provide for the first time experimental evidence for the potential functional role of cerebellar LTP, and it puts together currently available cell physiological and structural mechanisms into a new integrative hypothesis that is compatible with several existing lines of research.

Our finding that female gonadal hormones can improve motor learning may have several teleological implications. First, the improved ability for particular forms of cerebellar motor learning may be related to specific needs during the short period of proestrus in which females need to find, attract, and have intercourse with appropriate males. In this sense, the observed effect can be considered as a sexually dimorphic trait, because females with naturally occurring high levels of E2 outperformed males, who performed as well as females with naturally occurring low levels of E2. This characteristic is in line with other sexually dimorphic traits such as verbal abilities and fine motor skills in which females are also superior (Epting and Overman, 1998). Together, these procedural skills stand in contrast to some other traits in which males may be superior, such as visuospatial abilities (Epting and Overman, 1998). Second, changes in sexual hormones occur not only during the estrous cycle but also during pregnancy. Therefore, changes in Purkinje cell activities caused by changes in levels of E2 may also be related to pregnancy. During pregnancy, the increment of the abdominal size changes the center of gravity, which leads to an altered postural balance forcing the vestibulocerebellum to adapt to the new situation so as to make smaller movements such as error-free walking. Nonstumbling pregnant females have reproductive advantages. Obviously, during pregnancy, other types of behavior such as "nest making" also require hormonal changes, but it remains to be seen to what extent E2 alone can explain such complicated behaviors. In this respect, it is important to note that we did not only observe differences in VOR adaptation during the natural estrous cycle, in which the levels of other hormones such as progesterone also vary substantially, but that we also observed the same effects when we artificially altered the level of E2 alone.

The impact of E2 on cerebellar motor learning and plasticity does not stand on itself. E2 can promote dendritic outgrowth, spinogenesis, and synaptogenesis of Purkinje cells during neonatal life (Sakamoto et al., 2003; Shikimi et al., 2004), and it can enhance their responses to natural and pharmacological stimulation during adulthood (Smith et al., 1987; Smith, 1989). E2 also improves other forms of memory formation such as spatial reference memory and trace conditioning controlled by the hippocampus and forms of visual memory and strategy solving tasks controlled by the cerebral cortex (Frick et al., 2002; Luine et al., 2003; Leuner et al., 2004; Rhodes and Frye, 2004). In the hippocampus, E2 has also been shown to facilitate the formation of new synapses (Woolley and McEwen, 1993) and to exert a positive impact on induction of LTP (Cordoba Montoya and Carrer, 1997; Good et al., 1999; Vouimba et al., 2000). Thus, although short-term potentiating mechanisms such as those mediated by levels of calcium concentration and activation of kinases and phosphatases can vary substantially between hippocampal and cerebellar learning (Cordoba Montoya and Carrer, 1997; Good et al., 1999; Vouimba et al., 2000), sex hormone-related mechanisms appear to be able to overrule these differences and exert general effects in different brain regions. 


\section{References}

Adams MM, Shah RA, Janssen WG, Morrison JH (2001) Different modes of hippocampal plasticity in response to estrogen in young and aged female rats. Proc Natl Acad Sci USA 98:8071-8076.

Albus JS (1971) A theory of cerebellar function. Math Biosci 10:25-61.

Andreescu CE, De Ruiter MM, De Zeeuw CI, De Jeu MT (2005) Otolith deprivation induces optokinetic compensation. J Neurophysiol 94:3487-3496.

Barski JJ, Dethleffsen K, Meyer M (2000) Cre recombinase expression in cerebellar Purkinje cells. Genesis 28:93-98.

Belmeguenai A, Hansel C (2005) A role for protein phosphatases 1,2A, and 2B in cerebellar long-term potentiation. J Neurosci 25:10768-10772.

Blazquez PM, de Carrizosa MA, Heiney SA, Highstein SM (2007) Neuronal substrates of motor learning in the velocity storage generated during optokinetic stimulation in the squirrel monkey. J Neurophysiol 97:1114-1126.

Boyden ES, Raymond JL (2003) Active reversal of motor memories reveals rules governing memory encoding. Neuron 39:1031-1042.

Boyden ES, Katoh A, Raymond JL (2004) Cerebellum-dependent learning: the role of multiple plasticity mechanisms. Annu Rev Neurosci 27:581-609.

Coesmans M, Weber JT, De Zeeuw CI, Hansel C (2004) Bidirectional parallel fiber plasticity in the cerebellum under climbing fiber control. Neuron 44:691-700.

Collewijn H, Grootendorst AF (1979) Adaptation of optokinetic and vestibulo-ocular reflexes to modified visual input in the rabbit. Prog Brain Res 50:771-781.

Cordoba Montoya DA, Carrer HF (1997) Estrogen facilitates induction of long term potentiation in the hippocampus of awake rats. Brain Res 778:430-438.

De Zeeuw CI, Yeo CH (2005) Time and tide in cerebellar memory formation. Curr Opin Neurobiol 15:667-674.

De Zeeuw CI, Holstege JC, Ruigrok TJ, Voogd J (1989) Ultrastructural study of the GABAergic, cerebellar, and mesodiencephalic innervation of the cat medial accessory olive: anterograde tracing combined with immunocytochemistry. J Comp Neurol 284:12-35.

De Zeeuw CI, Hansel C, Bian F, Koekkoek SK, van Alphen AM, Linden DJ, Oberdick J (1998) Expression of a protein kinase C inhibitor in Purkinje cells blocks cerebellar LTD and adaptation of the vestibulo-ocular reflex. Neuron 20:495-508.

De Zeeuw CI, Koekkoek SKE, van Alphen AM, Luo C, Hoebeek F, van der Steen J, Frens MA, Sun J, Goossens HHLM, Jaarsma D, Coesmans MPH, Schmolesky MT, De Jeu MTG, Galjart N (2004) Gain and phase control of compensatory eye movements by the vestibulo-cerebellar system. In: Handbook of auditory research (Highstein S, ed), pp 375-421. New York: Springer.

Dupont S, Krust A, Gansmuller A, Dierich A, Chambon P, Mark M (2000) Effect of single and compound knockouts of estrogen receptors alpha (ERalpha) and beta (ERbeta) on mouse reproductive phenotypes. Development 127:4277-4291.

Epting LK, Overman WH (1998) Sex-sensitive tasks in men and women: a search for performance fluctuations across the menstrual cycle. Behav Neurosci 112:1304-1317.

Farr SA, Flood JF, Scherrer JF, Kaiser FE, Taylor GT, Morley JE (1995) Effect of ovarian steroids on footshock avoidance learning and retention in female mice. Physiol Behav 58:715-723.

Faulstich BM, Onori KA, du Lac S (2004) Comparison of plasticity and development of mouse optokinetic and vestibulo-ocular reflexes suggests differential gain control mechanisms. Vision Res 44:3419-3427.

Frick KM, Fernandez SM, Bulinski SC (2002) Estrogen replacement improves spatial reference memory and increases hippocampal synaptophysin in aged female mice. Neuroscience 115:547-558.

Gibbs RB, Burke AM, Johnson DA (1998) Estrogen replacement attenuates effects of scopolamine and lorazepam on memory acquisition and retention. Horm Behav 34:112-125.

Good M, Day M, Muir JL (1999) Cyclical changes in endogenous levels of oestrogen modulate the induction of LTD and LTP in the hippocampal CA1 region. Eur J Neurosci 11:4476-4480.

Hansel C, Linden DJ, D’Angelo E (2001) Beyond parallel fiber LTD: the diversity of synaptic and non-synaptic plasticity in the cerebellum. Nat Neurosci 4:467-475.

Hansel C, de Jeu M, Belmeguenai A, Houtman SH, Buitendijk GH, Andreev
D, De Zeeuw CI, Elgersma Y (2006) AlphaCaMKII Is essential for cerebellar LTD and motor learning. Neuron 51:835-843.

Ito M (1991) The cellular basis of cerebellar plasticity. Curr Opin Neurobiol 1:616-620.

Iwashita M, Kanai R, Funabiki K, Matsuda K, Hirano T (2001) Dynamic properties, interactions and adaptive modifications of vestibulo-ocular reflex and optokinetic response in mice. Neurosci Res 39:299-311.

Jakab RL, Wong JK, Belcher SM (2001) Estrogen receptor beta immunoreactivity in differentiating cells of the developing rat cerebellum. J Comp Neurol 430:396-409.

Jimenez-Diaz L, Navarro-Lopez Jde D, Gruart A, Delgado-Garcia JM (2004) Role of cerebellar interpositus nucleus in the genesis and control of reflex and conditioned eyelid responses. J Neurosci 24:9138-9145.

Koekkoek SK, Yamaguchi K, Milojkovic BA, Dortland BR, Ruigrok TJ, Maex R, De Graaf W, Smit AE, VanderWerf F, Bakker CE, Willemsen R, Ikeda T, Kakizawa S, Onodera K, Nelson DL, Mientjes E, Joosten M, De Schutter E, Oostra BA, Ito M, et al. (2005) Deletion of FMR1 in Purkinje cells enhances parallel fiber LTD, enlarges spines, and attenuates cerebellar eyelid conditioning in Fragile X syndrome. Neuron 47:339-352.

Leuner B, Mendolia-Loffredo S, Shors TJ (2004) High levels of estrogen enhance associative memory formation in ovariectomized females. Psychoneuroendocrinology 29:883-890.

Lev-Ram V, Wong ST, Storm DR, Tsien RY (2002) A new form of cerebellar long-term potentiation is postsynaptic and depends on nitric oxide but not cAMP. Proc Natl Acad Sci USA 99:8389-8393.

Lisberger SG, Miles FA, Optican LM (1983) Frequency-selective adaptation: evidence for channels in the vestibulo-ocular reflex? J Neurosci 3:1234-1244.

Lisberger SG, Pavelko TA, Bronte-Stewart HM, Stone LS (1994) Neural basis for motor learning in the vestibuloocular reflex of primates. II. Changes in the responses of horizontal gaze velocity Purkinje cells in the cerebellar flocculus and ventral paraflocculus. J Neurophysiol 72:954-973.

Luine VN, Jacome LF, Maclusky NJ (2003) Rapid enhancement of visual and place memory by estrogens in rats. Endocrinology 144:2836-2844.

Marr D (1969) A theory of cerebellar cortex. J Physiol (Lond) 202:437-470.

Miles FA, Eighmy BB (1980) Long-term adaptive changes in primate vestibuloocular reflex. I. Behavioral observations. J Neurophysiol 43:1406-1425.

Mukai H, Tsurugizawa T, Murakami G, Kominami S, Ishii H, Ogiue-Ikeda M, Takata N, Tanabe N, Furukawa A, Hojo Y, Ooishi Y, Morrison JH, Janssen WG, Rose JA, Chambon P, Kato S, Izumi S, Yamazaki T, Kimoto, T, Kawato S (2007) Rapid modulation of long-term depression and spinogenesis via synaptic estrogen receptors in hippocampal principal neurons. J Neurochem 100:950-967.

O’Neal MF, Means LW, Poole MC, Hamm RJ (1996) Estrogen affects performance of ovariectomized rats in a two-choice water-escape working memory task. Psychoneuroendocrinology 21:51-65.

Perez SE, Chen EY, Mufson EJ (2003) Distribution of estrogen receptor alpha and beta immunoreactive profiles in the postnatal rat brain. Brain Res Dev Brain Res 145:117-139.

Price Jr RH, Handa RJ (2000) Expression of estrogen receptor-beta protein and mRNA in the cerebellum of the rat. Neurosci Lett 288:115-118.

Rhodes ME, Frye CA (2004) Estrogen has mnemonic-enhancing effects in the inhibitory avoidance task. Pharmacol Biochem Behav 78:551-558.

Robinson DA (1976) Adaptive gain control of vestibuloocular reflex by the cerebellum. J Neurophysiol 39:954-969.

Sakamoto H, Mezaki Y, Shikimi H, Ukena K, Tsutsui K (2003) Dendritic growth and spine formation in response to estrogen in the developing Purkinje cell. Endocrinology 144:4466-4477.

Shikimi H, Sakamoto H, Mezaki Y, Ukena K, Tsutsui K (2004) Dendritic growth in response to environmental estrogens in the developing Purkinje cell in rats. Neurosci Lett 364:114-118.

Shors TJ, Lewczyk C, Pacynski M, Mathew PR, Pickett J (1998) Stages of estrous mediate the stress-induced impairment of associative learning in the female rat. NeuroReport 9:419-423.

Shughrue PJ, Lane MV, Merchenthaler I (1997) Comparative distribution of estrogen receptor-alpha and -beta mRNA in the rat central nervous system. J Comp Neurol 388:507-525.

Smith SS (1989) Estrogen administration increases neuronal responses to excitatory amino acids as a long-term effect. Brain Res 503:354-357.

Smith SS, Waterhouse BD, Woodward DJ (1987) Sex steroid effects on ex- 
trahypothalamic CNS. I. Estrogen augments neuronal responsiveness to iontophoretically applied glutamate in the cerebellum. Brain Res 422:40-51

Song I, Huganir RL (2002) Regulation of AMPA receptors during synaptic plasticity. Trends Neurosci 25:578-588.

Stahl JS (2004) Using eye movements to assess brain function in mice. Vision Res 44:3401-3410.

Stahl JS, van Alphen AM, De Zeeuw CI (2000) A comparison of video and magnetic search coil recordings of mouse eye movements. J Neurosci Methods 99:101-110.

Strata P, Rossi F (1998) Plasticity of the olivocerebellar pathway. Trends Neurosci 21:407-413.

Van Alphen AM, De Zeeuw CI (2002) Cerebellar LTD facilitates but is not essential for long-term adaptation of the vestibulo-ocular reflex. Eur J Neurosci 16:486-490.
Vouimba RM, Foy MR, Foy JG, Thompson RF (2000) 17Beta-estradiol suppresses expression of long-term depression in aged rats. Brain Res Bull 53:783-787.

Warren SG, Humphreys AG, Juraska JM, Greenough WT (1995) LTP varies across the estrous cycle: enhanced synaptic plasticity in proestrus rats. Brain Res 703:26-30.

Welsh JP, Harvey JA (1991) Pavlovian conditioning in the rabbit during inactivation of the interpositus nucleus. J Physiol (Lond) 444:459-480.

Woolley CS, McEwen BS (1992) Estradiol mediates fluctuation in hippocampal synapse density during the estrous cycle in the adult rat. J Neurosci 12:2549-2554.

Woolley CS, McEwen BS (1993) Roles of estradiol and progesterone in regulation of hippocampal dendritic spine density during the estrous cycle in the rat. J Comp Neurol 336:293-306.

Zucker RS (1989) Short-term synaptic plasticity. Annu Rev Neurosci 12:13-31. 